\title{
Physiology and production of yellow passion fruit with hydroabsorbent polymer and different irrigation depths ${ }^{1}$
}

\author{
Adailza Guilherme Cavalcante ${ }^{2}$ (D) , Lourival Ferreira Cavalcante ${ }^{3}$, Antônio Gustavo de Luna Souto ${ }^{3}$, \\ Alian Cássio Pereira Cavalcante ${ }^{4 *} \mathbb{D}$, Danila Lima de Araújo ${ }^{3}$, Ana Paula Pereira do Nascimento ${ }^{3}$, José Cola Zanuncio ${ }^{5}$
}

10.1590/0034-737X202067050004

\begin{abstract}
The yellow passion fruit is grown under different edaphoclimatic conditions. Irrigation standardizes and increases the development and productivity of the plants. The objective of this study was to evaluate the physiological and productive aspects of yellow passion fruit with application of hydroabsorbent polymer at different irrigation depths. The experimental design was in randomized blocks in a $2 \times 5$ factorial arrangement. The treatments were soil with and without polymer and five dephts of irrigation (60 to 100\% of crop evapotranspiration). Initial, maximum, and variable chlorophyll fluorescence, physiology (photosynthetic rate, internal carbon concentration, transpiration, stomatal conductance, water use efficiency, and instantaneous carboxylation efficiency) and production of yellow passion fruit were the variables analyzed. The hydrogel probably retained water in its structure, reducing the ability to dissipate excess energy. Setting the irrigation depth at an estimated $82 \%$ of crop evapotranspiration increased photosynthetic rate, stomatal conductance, and water use efficiency of yellow passion fruit plants. Maximum yield was $17.2 \mathrm{t} \mathrm{ha}^{-1}$ in irrigated plants at $100 \%$ evapotranspiration (ETc) in soil without hydrogel.
\end{abstract}

Keywords: Production components; Passiflora edulis; Hydrogel; Irrigation management.

\section{INTRODUCTION}

Brazil is the world's largest producer and consumer of yellow passion fruit, with production reaching 700,000 tons in 2017 (Agrianual, 2018). The species of the genus Passiflora, which is the yellow passion fruit, it grows and produces under different edaphoclimatic conditions, with production beginning from six months after transplantation (Meletti, 2011).

Water deficiency in semi-arid regions decreases relative leaf water content, turgor pressure, cellular water potential, plant growth, and productivity (Efeoçlu et al., 2009), and this is also true for passion fruit (Godim et al., 2009). These declines are the result of reduced leaf metabolism due to decreased transpiration,
$\mathrm{CO}_{2}$ assimilation, loss of cell turgidity and stomatal opening (Melo et al., 2010; Zlatev \& Lidon, 2010; Kalaji et al., 2016).

Plants under water stress do not use all the light energy to produce ATP and NADPH because they progressively reduce photosynthesis (Martinazzo et al., 2013). This increases the susceptibility to photoinhibition by directly or indirectly affecting photosynthetic capacity and, consequently, the chlorophyll a fluorescence kinetics (Gomes et al., 2012). Besides that, the photoinhibition reduces the evolution of maximum $\mathrm{CO}_{2}$ yield and prolonged exposure to excess light increases the production of reactive oxygen species - ROS (Long \& Humphries, 1994). Plants reduce these damages by safely removing excess light by dissipating thermal energy facilitated by the

\footnotetext{
Submitted on March $31^{\text {th }}, 2020$ and accepted on August $7^{\text {th }}, 2020$

${ }^{1}$ This work is part of author Master's Thesis.

${ }^{2}$ Universidade Estadual Paulista, Departamento de Produção Vegetal, Jaboticabal, São Paulo, Brazil. adailzacavalcante@gmail.com.

${ }^{3}$ Universidade Federal da Paraíba, Centro de Ciências Agrárias, Areia, Paraíba, Brazil. lofeca1946@yahoo.com.br; gusluso@hotmail.com; anappnascimento@gmail.com. danilalimaraujo@hotmail.com

${ }^{4}$ Universidade Federal de Viçosa, Departamento de Fitotecnia, Viçosa, Minas Gerais, Brazil. cassio.alian216@gmail.com

${ }^{5}$ Universidade Federal de Viçosa, Departamento de Entomologia, Viçosa, Minas Gerais, Brazil. zanuncio@ufv.br

* Corresponding author: cassio.alian216@gmail.com
} 
association of zeaxanthin and PsbS protein, a process called photoprotection (Demmig-Admas \& Admas III, 2006; Pinnola \& Bassi, 2018).

Among the technologies that offer an alternative for more efficient water use in Brazil, the use of agricultural hydrogels has gained notoriety in the last decades (Monteiro Neto et al., 2017). Hydroabsorbent polymer (hydrogel) retains water, reducing nutrient leaching and improving cation exchange (Fagundes et al., 2015) as well as making water available to plants (Felippe et al., 2016). Hydroabsorbent polymers are used for the formation and growth of lettuce (Lactuca sativa L.) and cowpea (Vigna unguiculata (L.) Walp) seedlings (Santos et al., 2015; Lopes et al., 2017), but their use in the cultivation of yellow passion fruit requires more research. These polymers promote greater water and nutrient retention, releasing more slowly to plants due to absorption-release cycles and irrigation depths that allow water levels to be maintained (Bernardi et al., 2012; Fagundes et al., 2015).

The objective of this work was to evaluate physiological and productive aspects of yellow passion fruit with the use of hydroabsorbent polymer at different irrigation depths.

\section{MATERIAL AND METHODS}

The experiment was carried out from September 2016 to June 2017 at Macaquinhos site, Remígio, Paraíba State, Brazil (latitude 6 53' 00" South, longitude $36^{\circ} 02^{\prime}$ 00" West, altitude $470 \mathrm{~m}$ ). The climate of the region, according to the Köppen classification, is As', which means hot and humid, with concentrated rainfall from March to July (Alvares et al., 2013). Temperature and relative humidity (obtained with Datalogger model HT-70, Instrutherm Instrumentos de Medição Ltda, São Paulo), quantified rainfall in pluviometer and evaporation rates measured in the Class "A" tank during the experiment were recorded (Table 1).

The soil of the experimental area was classified, according to the Brazilian Soil Classification System (Embrapa, 2013), as Dystrophic Regolithic Neossol type with the following chemical characterization: $\mathrm{pH}\left(\mathrm{H}_{2} \mathrm{O}\right)=$ 7.3; $\mathrm{P}=352\left(\mathrm{mg} \mathrm{dm}^{-3}\right) ; \mathrm{K}^{+}=474\left(\mathrm{mg} \mathrm{dm}^{-3}\right) ; \mathrm{Na}^{+}=1,094$ $\left(\mathrm{cmol}_{\mathrm{c}} \mathrm{dm}^{-3}\right) ; \mathrm{H}^{2+} \mathrm{Al}^{3+}=1.90\left(\mathrm{cmol}_{\mathrm{c}} \mathrm{dm}^{-3}\right) ; \mathrm{Al}^{3+}=0.00\left(\mathrm{cmol}_{\mathrm{c}}\right.$ $\left.\mathrm{dm}^{-3}\right) ; \mathrm{Ca}^{2+}=6.55\left(\mathrm{cmol}_{\mathrm{c}} \mathrm{dm}^{-3}\right) ; \mathrm{Mg}^{2+}=3.98\left(\mathrm{cmol}_{\mathrm{c}} \mathrm{dm}^{-3}\right)$; base sum $=13.69\left(\mathrm{cmol}_{\mathrm{c}} \mathrm{dm}^{-3}\right)$; cation exchange capacity $=$ $15.58\left(\mathrm{cmol}_{\mathrm{c}} \mathrm{dm}^{-3}\right)$; exchangeable base saturation $=87.87$ $(\%)$; organic matter $=24.15\left(\mathrm{~g} \mathrm{~kg}^{-1}\right)$ and physical: sand $=$ $830(\mathrm{~mm})$; silt $=113(\mathrm{~mm})$; clay $=57(\mathrm{~mm})$; dispersed clay in water $=25\left(\mathrm{~g} \mathrm{~kg}^{-1}\right)$; degree of flocculation $=56.14(\%)$; soil density $=1.36\left(\mathrm{~g} \mathrm{~cm}^{-3}\right)$; particle density $=2.58\left(\mathrm{~g} \mathrm{~cm}^{-3}\right)$; total porosity $=48.68(\%)$; moisture at water energy level at field capacity $0.010 \mathrm{Mpa}=107\left(\mathrm{~g} \mathrm{~kg}^{-1}\right)$; moisture at water energy level at permanent withering point $1,500 \mathrm{Mpa}$ $=58\left(\mathrm{~g} \mathrm{~kg}^{-1}\right)$; available water $=49\left(\mathrm{~g} \mathrm{~kg}^{-1}\right)$; textural class $=$ open soil sand.

Treatments were distributed in randomized blocks in a $2 \times 5$ factorial arrangement with or without hydroabsorbent polymer and at irrigation depths of 100, 90, 80, 70, and $60 \%$ of crop evapotranspiration (ETc), with four replications. Each experimental unit was represented by a $3 \times 3 \mathrm{~m}$ spaced plant conducted in a plastic container, as pressure lysimeter, with dimensions of diameter $0.60 \mathrm{~m}$, height $0.50 \mathrm{~m}$, area $0.28 \mathrm{~m}^{2}$ and volume $140 \mathrm{dm}^{3}$, adding $140 \mathrm{~kg}$ of substrate. In the lower base of the pressure lysimeter, two hose drains with a nominal diameter of 13 $\mathrm{mm}$ were installed to collect the leached volume, mainly in treatments with the largest depth irrigation.

The physical properties of the Hydroplan ${ }^{\circledR}$ waterabsorbent polymer EB/HyA (Empresa de Base \& Distribuidora Ltda - Hydroplan-EB, São Paulo) are: appearance $=$ white granules, particle size $=0.5$ to $3 \mathrm{~mm}$; anionic, active ingredient $(\%$ solids content $)=100$, water content $(\%)=$ 10 , volume density $\left(\mathrm{g} \mathrm{cm}^{-3}\right)=0.8$ and solubility $=$ insoluble in water. This polymer was applied at a dose of $1 \mathrm{~g} \mathrm{~kg}^{-1}$ for sandy soils, according to the manufacturer's suggestion and applied in four stations, one per quadrant of the lysimeter, installed at $0.10 \mathrm{~m}$ from the wall, $0.20 \mathrm{~m}$ of the plant stem, and $0.20 \mathrm{~m}$ deep. The substrate before the installation of the stations, was moistened to collect 0.4 $\mathrm{dm}^{3}$, mixed with $35 \mathrm{~g}$ of the polymer and returned to the lysimeter. The seeds of passion fruit were obtained from fruits of a commercial orchard of plants submitted to mass selection. These were plants of the local variety ('Guinezinho') that is traditionally grown in the municipality of Nova Floresta, Paraíba State, Brazil (Medeiros et al., 2016).

Substrate humidity was increased to field capacity one day before seedling transplantation, with water applied until the beginning of the drainage and the applied and drained volume after $24 \mathrm{~h}$. This allowed obtaining the humidity at field capacity level by difference between them. The passion fruit seedlings were transplanted in soil with field capacity moisture and irrigated every two days with ETc irrigation depths corresponding to 60, 70, 80, 90 and 100\% ETc, respectively: 492.1; 574.1; 656.1; 738.1 and 820.1 $\mathrm{L}_{\text {plant }}{ }^{-1}$ during the crop cycle from September 2016 to June 2017.

Irrigation was performed according to crop evapotranspiration (TEa), calculated as the product of tank evaporation class 'A' (Eta), between reference evapotranspiration $\left(\mathrm{ET}_{0}\right)$ and 0.75$)$ and the crop coefficient kc (Stone \& Silveira, 1995). The crop coefficients adopted for the yellow passion fruit were 0.40 of the seedling transplant period up to 60 days after transplantation (DAT), 0.64 of the period from 60 to 90 DAT, from 0.96 of the 90 to 
120 DAT and 1.2 out of 120 DAT until the end of the harvest (Freire et al., 2011).

The passion fruit seedlings, with a height of 15 to 20 $\mathrm{cm}$ and three pairs of leaves, were transplanted and supported in a simple trellis with a flat wire no. 12 to $2.7 \mathrm{~m}$ high at the top of the poles. The plants grew in a single stem up to the support wire when the bud was pruned 10 $\mathrm{cm}$ above the trellis for growth emission of the productive branches (Freire et al., 2011).

The fertilization of yellow passion fruit was carried out, monthly, from 30 to 120 DAT, with nitrogen (urea, $45 \% \mathrm{~N}$ ) and potassium (potassium chloride, $60 \% \mathrm{~K}_{2} \mathrm{O}$ ) in the proportion of $1: 1$, applying 5, 10 and $15 \mathrm{~g}$ of $\mathrm{N}$ and 60 , 90 and $120 \mathrm{~g}$ of K. From 120 DAT until the end of the harvest, monthly, were applied $20 \mathrm{~g}$ of $\mathrm{N}$ and $20 \mathrm{~g}$ of $\mathrm{K}$ in the form of urea and potassium chloride. Phosphate fertilization was $5 \mathrm{~g}$ plant $^{-1}$ of $\mathrm{P}$ as simple superphosphate $\left(18 \% \mathrm{P}_{2} \mathrm{O}_{5}, 20 \% \mathrm{Ca}^{2+}\right.$ and $12 \% \mathrm{~S}$ ) every two months from 60 DAT, totaling $20 \mathrm{~g} \mathrm{plant}^{-1}$ of $\mathrm{P}$ and 22, $22 \mathrm{~kg} \mathrm{ha}^{-1}$.

Chlorophyll a fluorescence was determined in the morning on the third fully developed leaf from the Plant Efficiency Analyzer PEA II® Modulated Fluorometer branch apical meristem (Opti-Sciences, USA). The leaves were dark adapted for $30 \mathrm{~min}$ with the use of the fluorometer forceps (Freire et al., 2014). The initial $\left(\mathrm{F}_{0}\right)$, variable (Fv) and maximum $(\mathrm{Fm})$ fluorescence and the ratio $\left(\mathrm{Fv} / \mathrm{F}_{0}\right)$ and quantum efficiency of photosystem II $(\mathrm{Fv} / \mathrm{Fm})$ were quantified (Maxwell \& Johnson, 2000).

Gas exchange was evaluated with a portable infrared radiation (IRGA) carbon analyzer (LCPro + Portable Photosynthesis System ${ }^{\circledR}$, ADC BioScientificLimted, United Kingdom) at $25^{\circ} \mathrm{C}, 1,800 \mu \mathrm{mol}$ photons $\mathrm{m}^{-2} \mathrm{~s}^{-1}$ irradiation, and flow rate of $200 \mathrm{~mL}$ air $\mathrm{min}^{-1}$. The physiological readings, taking the weighted average of the measured values, were made from two completely developed yellow passion fruit leaves (one per quadrant of the third pair of leaves from the apical meristem of the branches). The physiological variables photosynthetic rate $(\mathrm{A})$, internal carbon concentration $(\mathrm{Ci})$, transpiration rate $(\mathrm{E})$, stomatal conductance (gs), water use efficiency (A/E) and instantaneous carboxylation efficiency (A/Ci) were determined with IRGA (Freire et al. 2014).

The fruits were harvested from March to July 2017 and counted, and their mass obtained in a 0.1 -g precision electronic scale. The total number and average fruit mass and yield were obtained at the end of harvest. The data were subjected to analysis of variance by the F test at $5 \%$ probability. The mean for the hydrogel were compared using the F test $(\mathrm{p}<0.05)$, which is conclusive for two factors from the same source of variation. The results, at the different irrigation depths, were analyzed by regression with the Statistical Analysis System software.

\section{RESULTS AND DISCUSSION}

The initial, variable and maximum fluorescence ratios were higher in plants without hydrogel, with values of $64.5,320.0$, and 384.6 and 13.6, 12.1, and $12.7 \%$ higher, respectively, than those obtained with the polymer (Figure1A, B, and C). Under conditions of low availability of water resources, for example, chlorophylls have mechanisms called 'non-photochemical extinction' which are measures of reducing fluorescence by a pulse of saturating light, in addition to preventing the arrival of light by displacing the LCHII antenna of the PSII to PSI (Pinolla \& Bassi, 2018). The quantum efficiency of PSII in yellow passion fruit increased with irrigation depths.

Table 1: Precipitation (P), evaporation in tank class “A” (ET “A”), temperature (T) and relative humidity (RH) in 2016 and 2017 in the experimental area in Macaquinhos' site, municipality of Remigio, Paraíba State, Brazil

\begin{tabular}{|c|c|c|c|c|c|c|c|c|}
\hline \multicolumn{9}{|c|}{ Year 2016} \\
\hline Months & $\begin{array}{c}\mathbf{P} \\
\mathbf{m m}\end{array}$ & $\begin{array}{c}\text { ET “A" } \\
\text { Mm }\end{array}$ & $\begin{array}{c}\mathbf{T} \\
{ }^{\circ} \mathbf{C}\end{array}$ & $\begin{array}{c}\text { RH } \\
\%\end{array}$ & $\begin{array}{c}\mathbf{P} \\
\mathbf{m m}\end{array}$ & $\begin{array}{c}\text { ET "A" } \\
\text { mm }\end{array}$ & $\begin{array}{c}\text { RH } \\
\%\end{array}$ & $\begin{array}{c}\mathbf{T} \\
{ }^{\circ} \mathbf{C}\end{array}$ \\
\hline January & - & - & - & - & 10 & 6.7 & 70.2 & 20.8 \\
\hline February & - & - & - & - & 9 & 6.8 & 66.4 & 21.4 \\
\hline March & - & - & - & - & 58 & 6.5 & 80.8 & 21.5 \\
\hline April & - & - & - & - & 54 & 4.7 & 81.2 & 27.0 \\
\hline May & - & - & - & - & 77 & 4.6 & 76.1 & 24.7 \\
\hline June & - & - & - & - & 75 & 4.5 & 75.3 & 22.6 \\
\hline July & - & - & - & - & - & - & - & - \\
\hline August & - & - & - & - & - & - & - & - \\
\hline September & 19 & 6.2 & 25.3 & 75.6 & - & - & - & - \\
\hline October & 10 & 8.2 & 26.2 & 76.2 & - & - & - & - \\
\hline November & 0 & 8.3 & 27.1 & 75.2 & - & - & - & - \\
\hline December & 103 & 7.3 & 20.7 & 77.3 & - & - & - & - \\
\hline Total / Average & 733 & 5.8 & 24.8 & 76.1 & 283.0 & 5.6 & 75.0 & 23.0 \\
\hline
\end{tabular}

- = months without data collection of the respective variables. 
The other variables were similar between treatments (Table 2).

The initial, maximum, and variable fluorescence of plants without hydrogel in this study differ from the results obtained in lettuce (Lactuca sativa L.) and watermelon (Citrullus lanatus) plants, which showed higher fluorescence values after application of the waterabsorbent polymer (Melo et al., 2010; Beig et al., 2014). The polymer used in these studies was the same as that used in our study of yellow passion fruit. "The difference in fluorescence values may be due to the fact that the hydrogel had adsorbed water on its structure, thus limiting the availability of water to the plants". On the other hand, water that was not absorbed by the hydrogel was readily available in the soil without polymer, and the photosystem II absorption system increased the effectiveness of photosynthesis (Kelling et al., 2017). We conclude that addition of hydrogel in the soil reduces water availability, decreasing the fluorescence heat dissipation of passion fruit.

The quantum yield was the yellow passion fruit was higher in plants irrigated with a depth of $100 \%$ ETc
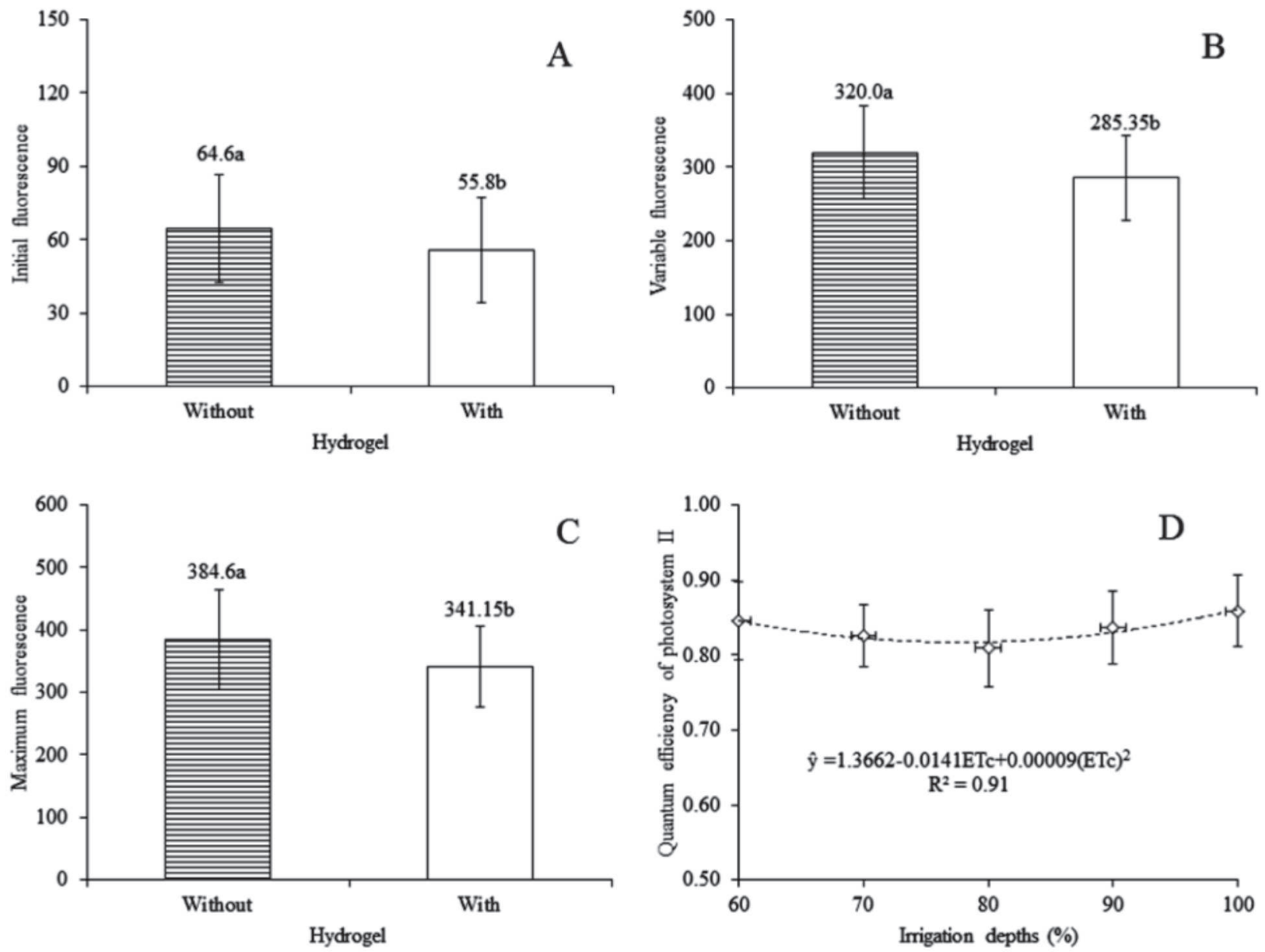

Figure 1: Initial (A), variable (B) and maximum (C) fluorescence with or without water-absorbent polymer in soil and quantum yield (D) in yellow passion fruit plants irrigated with different water depths $(n=40)$.

Table 2: Summary of analysis of variance by mean square for chlorophyll initial (F0), maximum (Fm) and variable (Fv) fluorescence and quantum efficiency. photosystem II (Fv/Fm) in yellow passion fruit plants with or without hydroabsorbent polymer (Pol.) irrigated with irrigation depths (Lam.)

\begin{tabular}{|c|c|c|c|c|c|c|c|}
\hline \multirow{2}{*}{ FV } & \multicolumn{2}{|c|}{$\mathbf{P}$} & \multicolumn{2}{|c|}{$\mathbf{L}$} & \multicolumn{2}{|c|}{$\mathbf{P} \times \mathbf{L}$} & \multirow{2}{*}{$\frac{\mathrm{CV}}{(\%)}$} \\
\hline & $\mathbf{F}$ & $p$ & $\mathbf{F}$ & $p$ & $\mathbf{F}$ & $P$ & \\
\hline F0 & 9.846 & $0.0491^{*}$ & 4.482 & $0.6100^{\mathrm{ns}}$ & 1.051 & $0.5000^{\mathrm{ns}}$ & 20.05 \\
\hline $\mathrm{Fm}$ & 9.181 & $0.0010^{* *}$ & 0.352 & $0.8405^{\text {ns }}$ & 1.783 & $0.1714^{\mathrm{ns}}$ & 14.37 \\
\hline $\mathrm{Fv}$ & 6.754 & $0.0123^{*}$ & 0.443 & $0.7714^{\mathrm{ns}}$ & 1.632 & $0.2026^{\mathrm{ns}}$ & 15.41 \\
\hline $\mathrm{Fv} / \mathrm{Fm}$ & 0.872 & $0.3673^{\mathrm{ns}}$ & 3.272 & $0.0324^{*}$ & 0.454 & $0.7671^{\mathrm{ns}}$ & 3.79 \\
\hline
\end{tabular}

$\mathrm{FV}=$ Source of variation; $\mathrm{F}=$ F-test value; $p=\mathrm{p}$-value; $\mathrm{CV}=$ Coefficient of variation; ${ }^{\mathrm{n}}=$ not significant; ${ }^{*}$ significant of $5 \%$ de probability; $* *$ significant of $1 \%$ de probability. 
(Figure1D). This increase was $82.41 \%$ over that seen at $60 \%$ ETc. Similar increases in quantum yield under adequate water supply conditions and reduction in water deficit conditions have been reported for plum (Prunus domestica L.) plants in a greenhouse (Martinazzo et al., 2013).

The reduction in quantum yield of yellow passion fruit plants in the $60 \%$ ETc treatment indicates that water stress causes photoinhibition of PSII photochemical reaction centers, increasing non-photochemical "cooling”, which inhibits the repair cycle of the plants (Long \& Humphries, 1994). Damaged reaction and unbalancing the value of the rate of excitation and electron transfer (Efeoçlu et al., 2009; Kalaji et al., 2016). However, the activity of the PSI (ferredoxin) electron end acceptors under stress conditions with apparent increase in PSI efficiency need not be further studied, as the electron flow from the PSII is directed to $\mathrm{NADP}^{+}$, reducing its use to $\mathrm{NADP}^{+}$, the formation of NADPH (Gomes et al., 2012). The irrigation depth of $60 \%$ ETc causes PSII quantum yield inhibition in passion fruit.

The hydrogel $\times$ irrigation depth interaction (Table 3 ) increased stomatal conductance, indicating that hydrogel reduces the frequency of water application without damage to the plants, as observed in Eucalyptus benthamii (Felippe et al., 2016). The irrigation depth increased photosynthetic rate and water use efficiency. The other variables were similar between treatments.

The photosynthetic rate of higher at the irrigation depth of $82 \%$ ETc (Figure 2A), being $9.5 \mu \mathrm{mol} \mathrm{CO} \mathrm{m}^{-2} \mathrm{~s}^{-1}$. In commercial cultivars of yellow passion fruit photosynthesis was higher, from 10.86 to $18.07 \mu \mathrm{mol} \mathrm{CO}_{2}$ $\mathrm{m}^{-2} \mathrm{~s}^{-1}$, with $100 \%$ ETc irrigation in Sooretama, Espirito Santo State, Brazil (Gama et al., 2013). The application of $82 \%$ of the water requirement of the crop was sufficient to meet the physiological processes without limiting the stomata influx of carbon dioxide and carbon assimilation (Amax) during photosynthetic processes (Zlatev \& Lidon, 2012).

The stomatal conductance of yellow passion fruit plants, grown on substrate without and with waterabsorbent polymer, respectively, increased in of 0.18 and $0.15 \mathrm{~mol} \mathrm{~m}^{-2} \mathrm{~s}^{-1}$ at irrigation levels of 81 and $82 \% \mathrm{ETc}$, respectively increased with peak with estimated blades of 81 and $82 \%$ ETc, 0.18 and $0.15 \mathrm{~mol} \mathrm{~m}^{-2} \mathrm{~s}^{-1}$, and decreased with those above the estimated maximums (Figure 2B). These results are similar to those of yellow passion fruit cultivars grown in Sooretama, Espirito Santo State, Brazil: 0.11 to $0.18 \mathrm{~mol} \mathrm{~m}^{-2} \mathrm{~s}^{-1}$ when irrigated at $100 \%$ water requirement (Gama et al., 2013). The stomatal closure and, consequently, the reduction in $\mathrm{CO}_{2}$ flow towards the carboxylation sites is one of the factors responsible for the reduction of photosynthetic activity.
Water use efficiency (A/E) increased with water availability with an estimated maximum value of 4.82 at an irrigation depth of $82 \%$ ETc (Figure 2C). Water requirements vary with plant species, and passion fruit plants use adaptive strategies to reduce water use and maximize biomass production by increasing carbon uptake and photosynthetic rate and reducing transpiration (Boutraa, 2010). The increase in water depth applied to the sweet potato (Ipomoea batatas (L.) Lam.) has increased the EUA to $87.3 \%$ ETc (Mantovani et al., 2013). Water use efficiency in sweet pepper plants was higher at $70 \%$ of crop requirement (Cardozo et al., 2016).

The results indicate that passion fruit plants, even with water depth reduction below the standard crop requirement, adjusted to the conditions of low water availability in the soil. This increase in water use efficiency occurred by increasing A/E ratio; i.e., increased photosynthesis efficiency and decreased respiratory rate (Wang et al., 2012).

The average fruit mass and yield of yellow passion fruit plants showed between polymer $\times$ irrigation depth interaction and the number of fruits responded to the isolated effect of hydrogel and irrigation depths (Table 3 ), with higher values of slides of $100 \%$ ETc and without soil without hydrogel. An adequate amount of water in the soil is necessary to maintain passion fruit productivity; lack of water impairs the development of sprouts and flowers, in direct relation with the production of fruits and plant productivity (Carr, 2013). Irrigation management reduces water deficit effects and increases yellow passion fruit productivity (Freire et al., 2014; Fagundes et al., 2015).

The number of fruits per plant increased with the availability of water (Figure $3 \mathrm{~A}$ ), from 37 to 46 fruits plant ${ }^{-1}$ and $24.3 \%$ gains between the 60 and $100 \%$ ETc treatments. Adequate irrigation and water availability at $100 \%$ ETc allow for a more homogeneous development of passion fruit, increasing the number of fruits harvested per plant and, consequently, the productivity of this plant (Godim et al., 2009).

In our study, the number of fruits was $11.5 \%$ lower with the hydroadsorbent treatment (Figure 3B), with a reduction of approximately five fruits plant ${ }^{-1}$. The fruit yield was higher, with 74 fruits plant ${ }^{-1}$ at an irrigation level of $100 \%$ ETc, as required by the crop (Araújo et al., 2012). The reduction in the number of fruits is due to the unavailability of water absorbed by the polymer to the plants during flower bud formation and flower pollination, thereby increasing the fruit loss in the field.

The average mass of fruit increased with irrigation depths due to higher water availability, as greater gains in soil plants without hydrogel (Figure 4A). The fruit mass 
was higher at $100 \%$ ETc (100\% of the culture requirement) without the polymer, at $317.52 \mathrm{~g}$ each. This value is higher than the average mass of yellow passion fruit produced in a conventional system ( $156.13 \mathrm{~g}$, Paulistânia municipality, Sao Paulo State, Brazil) and in an organic cultivation system (175.27 g, Remigio municipality, Paraiba State, Brazil), both reported by Fischer et al. (2007) and $139.5 \mathrm{~g}$ in irrigated plants with a $13.1 \mathrm{~mm}$, respectively in Paulistânia municipality, São Paulo State and Remigio municipality, Paraíba State, both in Brazil (Godim et al. 2009).

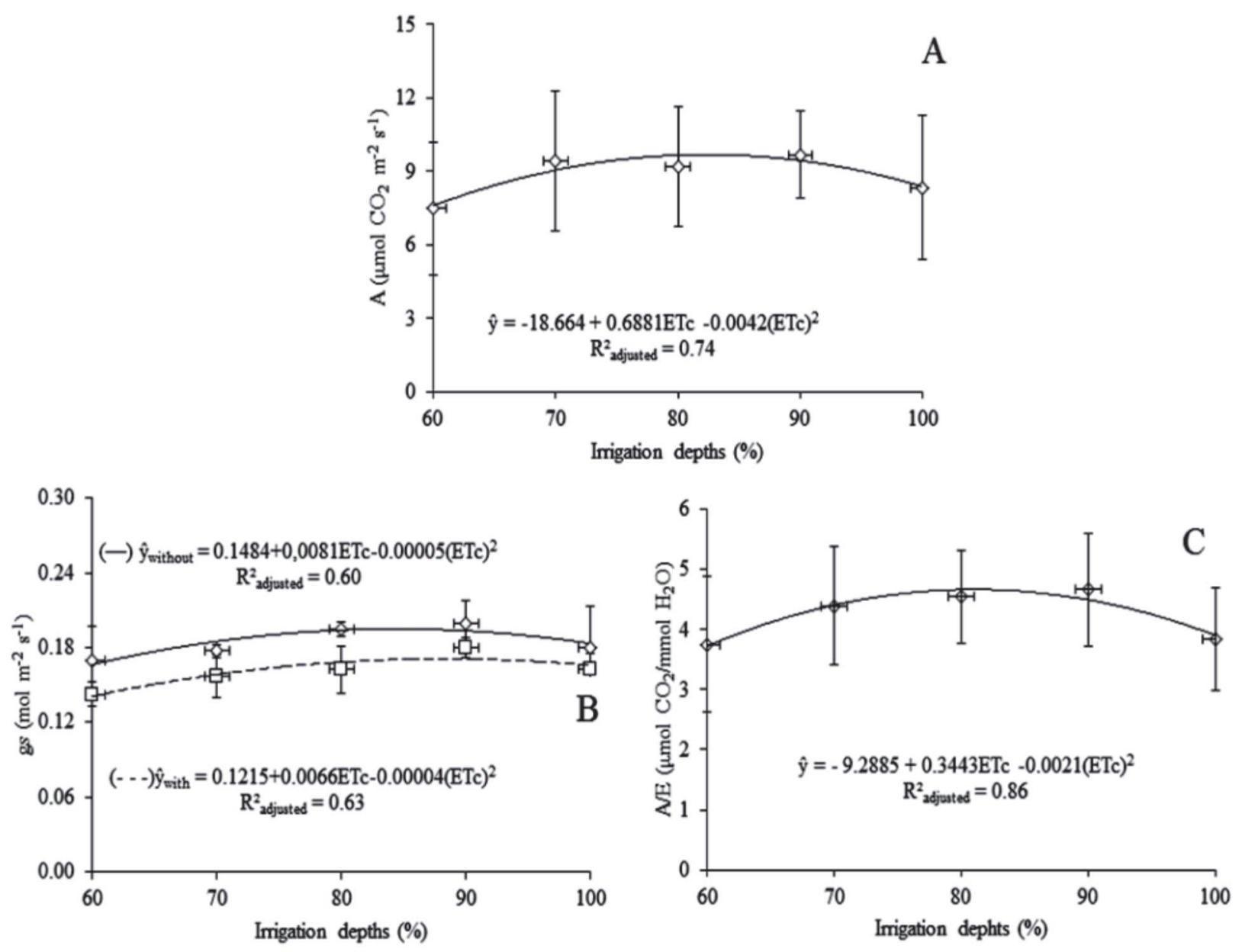

Figure 2: Photosynthetic rate (A), stomatal conductance (B) and water use efficiency (C) in yellow passion fruit plants irrigated with different irrigation depths and in soil without $(-)$ and with $(--)$ hydroabsorbent polymer. $(n=40)$.

Table 3: Summary of analysis of variance, by square mean, of photosynthetic rate (A), internal carbon concentration (Ci), transpiration (E), stomatal conductance (gs), water use efficiency (A/E) and instantaneous efficiency of carboxylation (A/Ci), number of fruits per plant (NFP), average fruit mass (MMF) and yield (PROD) per yellow passion fruit plant with or without hydroabsorbent polymer (Pol.) with different blades (Lam.) irrigation

\begin{tabular}{|c|c|c|c|c|c|c|c|}
\hline \multirow{2}{*}{ FV } & \multicolumn{2}{|c|}{$\mathbf{P}$} & \multicolumn{2}{|c|}{$\mathbf{L}$} & \multicolumn{2}{|c|}{$\mathbf{P} \times \mathbf{L}$} & \multirow{2}{*}{$\frac{\mathrm{CV}}{(\%)}$} \\
\hline & $\mathbf{F}$ & $p$ & $\mathbf{F}$ & $p$ & $\mathbf{F}$ & $P$ & \\
\hline A & 4.432 & $0.0530^{\mathrm{ns}}$ & 4.693 & $0.0011^{* *}$ & 0.276 & $0.8822^{\text {ns }}$ & 16.98 \\
\hline $\mathrm{Ci}$ & 0.024 & $0.8824^{\mathrm{ns}}$ & 0.486 & $0.7451^{\mathrm{ns}}$ & 0.534 & $0.7141^{\mathrm{ns}}$ & 12.32 \\
\hline $\mathrm{E}$ & 0.224 & $0.6410^{\mathrm{ns}}$ & 1.976 & $0.1435^{\mathrm{ns}}$ & 0.252 & $0.9260^{\mathrm{ns}}$ & 13.67 \\
\hline$g_{S}$ & 0.216 & $0.0121^{*}$ & 2.093 & $0.0043^{* *}$ & 0.015 & $0.0313^{*}$ & 8.26 \\
\hline $\mathrm{A} / \mathrm{E}$ & 7.773 & $0.1431^{\mathrm{ns}}$ & 5.542 & $0.0010^{* *}$ & 1.344 & $0.2971^{\mathrm{ns}}$ & 16.65 \\
\hline $\mathrm{A} / \mathrm{Ci}$ & 3.874 & $0.0613^{\mathrm{ns}}$ & 3.135 & $0.0634^{\mathrm{ns}}$ & 0.375 & $0.8263^{\mathrm{ns}}$ & 17.48 \\
\hline NFP & 5.460 & $0.0271^{*}$ & 3.928 & $0.0122^{*}$ & 1.220 & $0.3257^{\mathrm{ns}}$ & 16.61 \\
\hline MMF & 1.859 & $0.1839^{\mathrm{ns}}$ & 113.667 & $0.0000^{* * *}$ & 42.517 & $0.0000^{* *}$ & 4.62 \\
\hline PROD & 7.936 & $0.0090^{* *}$ & 17.027 & $0.0000^{* *}$ & 5.597 & $0.0021^{* *}$ & 16.62 \\
\hline
\end{tabular}

$\mathrm{FV}=$ Source of variation; $\mathrm{F}=\mathrm{F}$-test value; $p=\mathrm{p}$-value; $\mathrm{CV}=$ Coefficient of variation; ${ }^{\mathrm{n}}=$ not significant; ${ }^{*}$ significant of $5 \%$ de probability; $* *$ significant of $1 \%$ de probability. 
The polymer reduced the water depth required for plant production by increasing the retention of water that would otherwise be lost by evaporation, percolation, and lateral movement outside the root system. The fresh fruit mass of polymer-free plants was $4 \%$ higher at $82 \%$ ETc compared with fruit mass at $60 \%$ ETc. The average mass of passion fruit increased with irrigation levels, ranging from 160 to $300 \mathrm{~g}$, depending on the irrigation depth (Vasconcelos et al., 2013).

The productivity of yellow passion fruit plants was $11.5 \mathrm{t} \mathrm{ha}^{-1}$ higher with the water-absorbent polymer and estimated $88 \%$ ETc and $17.2 \mathrm{t} \mathrm{ha}^{-1}$ without the hydrogel and at $100 \%$ ETc (Figure 4B). Increasing irrigation depth increased yellow passion fruit productivity to $30 \mathrm{t} \mathrm{ha}^{-1}$ in Alvorada do Gurguéia, Piauí, Brazil (Vasconcelos et al., 2013). The yield of the yellow passion fruit genotype BRS Sol in the Cerrado in Nova Floresta municipality, Paraíba State, Brazil, was 13.08 t ha $^{-1}$ year${ }^{1}$ when irrigated with saline water and bovine biofertilizer (Aguiar et al., 2017).

The lower number of fruits (Figure 3B), average fruit mass (Figure 4A) and yield (Figure 4B) of yellow passion fruit grown with hydrogel are due to water adsorption by the polymer, thus impairing water availability to the plants. As a consequence, there is a reduction in the formation of flower buds reduced, flowers, and fruit, as reported for irrigated yellow passion fruit in Adamatina municipality, São Paulo State, Brazil (Cavichioli et al., 2006).
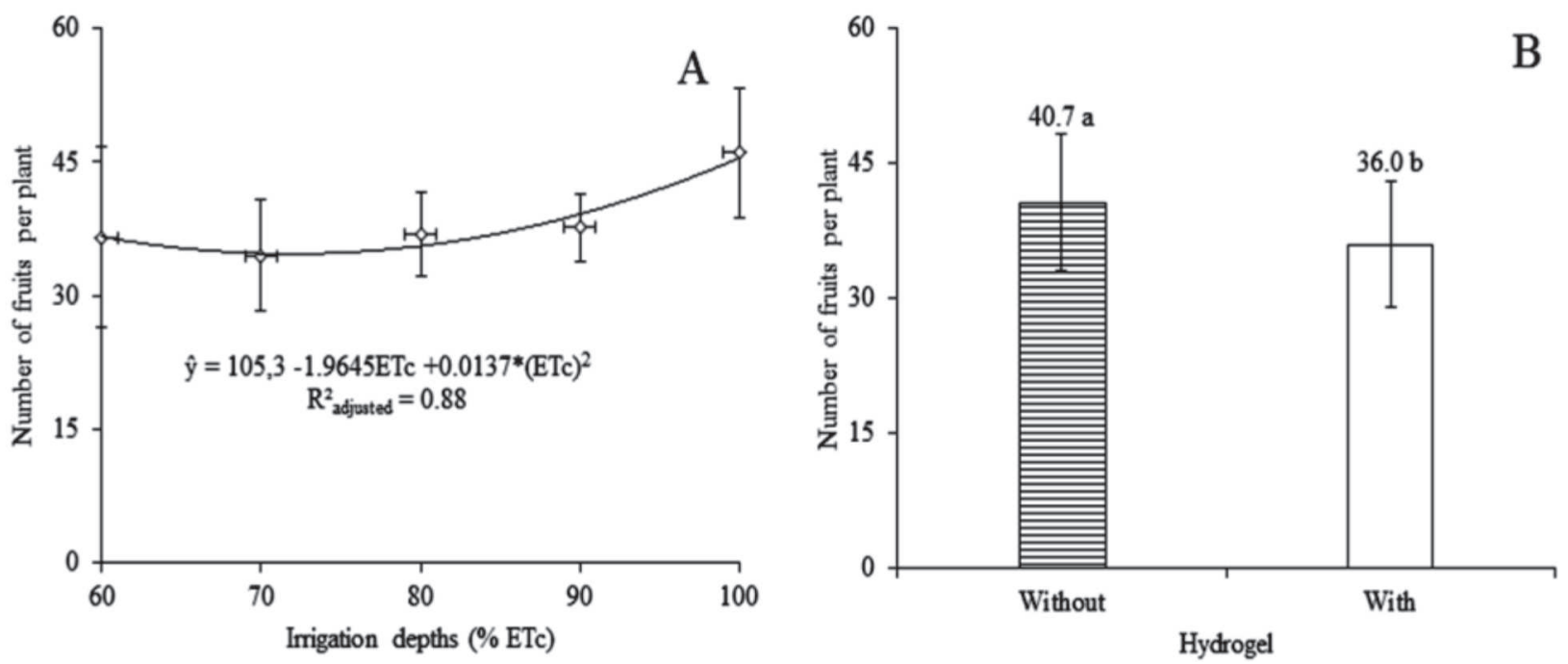

Figure 3: Number of fruits per yellow passion fruit plant with different irrigation depths (A) with or without hydroabsorbent polymer $(B) .(n=40)$.
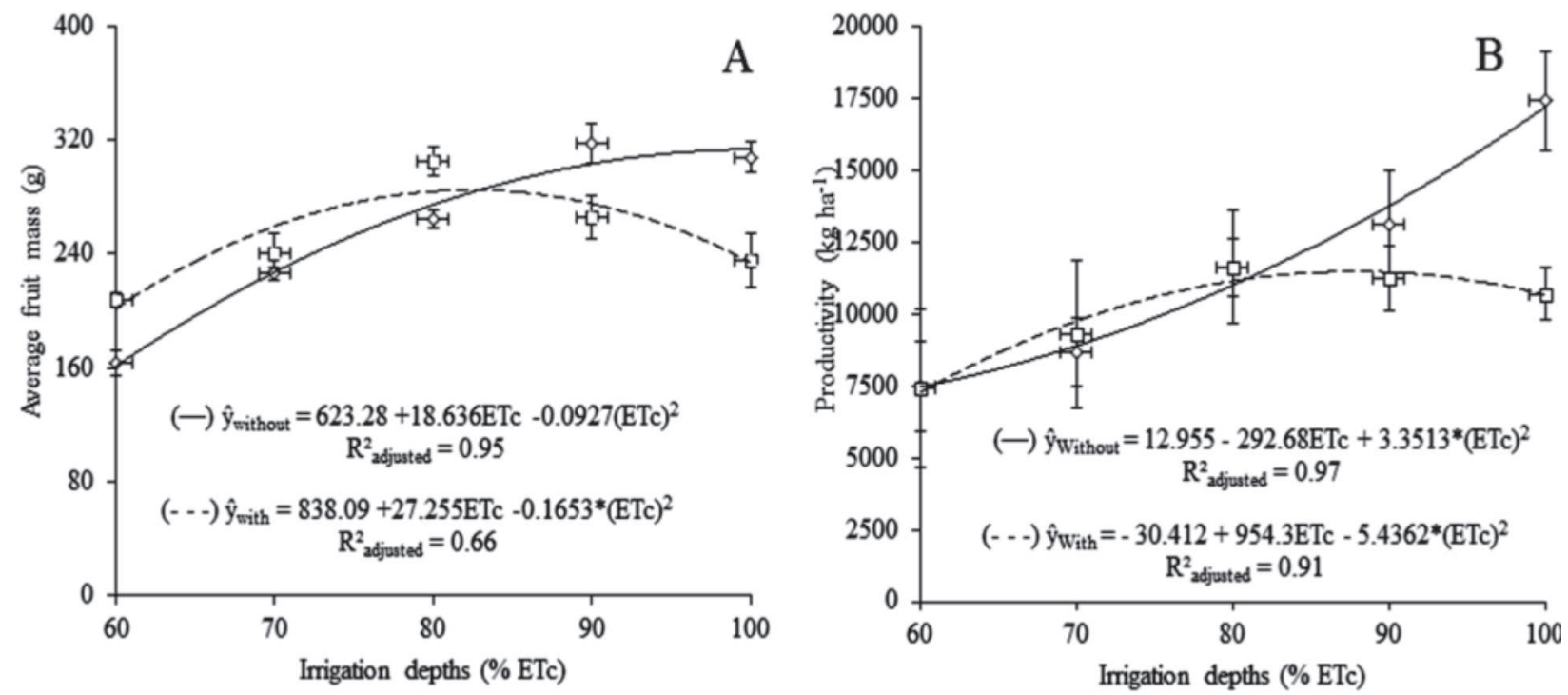

Figure 4: Average fruit mass (A) and yield of yellow passion fruit (B) with different irrigation depths into soil without ( - ) and with $(--)$ hydroabsorbent polymer. $(n=40)$. 


\section{CONCLUSION}

From the results, the hydrogel probably retained water in its structure and caused water stress in the yellow passion fruit, reducing the ability to dissipate excess energy. Photosystem II quantum yield, photosynthetic rate, stomatal conductance, and water use efficiency were more efficient at an estimated irrigation depth of $81 \%$ ETc without the presence of hydroabsorbent polymer to the substrate. The adequate supply of water $(100 \%$ of ETc) in the substrate without the hydrogel is the most indicated to increase the productive capacity of the yellow passion fruit.

\section{ACKNOWLEDGMENTS, FINNANCIAL SUPPORT AND FULL DISCLOSURE}

The Instituto Nacional de Ciência e Tecnologia em Salinidade (INCTSal) and to the Conselho Nacional de Desenvolvimento Científico e Tecnológico (CNPq) for the financial support and the granting of scholarship to the first author.

\section{CONFLICTS OF INTERESTS}

The authors declare that there is no conflict of interests.

\section{REFERENCES}

Agrianual (2018) Anuário Brasileiro de Fruticultura. Santa Cruz do Sul, Gazeta. 49 p

Aguiar AVM, Cavalcante LF, Silva RM, Dantas TAG \& Santos EC (2017) Effect of biofertilization on yellow passion fruit production and fruit quality. Revista Caatinga, 30:136-148.

Alvares CA, Stape JL, Sentelhas PC, Gonçalves JLM \& Sparovek G (2013) Koppen's climate classification map for Brazil. Meteorologische Zeitschrift, 22:711-728.

Araújo HF, Costa RNT, Crisóstomo JR, Saunders LCU, Moreira OC \& Araújo ABMM (2012) Produtividade e análise de indicadores técnicos do maracujazeiro-amarelo irrigado em diferentes horários. Revista Brasileira de Engenharia Agrícola e Ambiente, 16:159-164.

Bernardi MR, Sperotto Junior M, Daniel O \& Vitorin ACT (2012) Crescimento de mudas de Corymbia citriodora em função do uso de hidrogel e adubação. Cerne, 18:67-74.

Beig AVG, Neamati SH, Tehranifar A \& Emani H (2014) Evaluation of chlorophyll fluorescence and biochemical traits of lettuce (Lactuca sativa L.) under drought stress and super absorbent or bentonite application. Journal of Stress Physiology \& Biochemistry, 10:301-315.

Boutraa T (2010) Improvement of water use efficiency in irrigated agriculture: A review. Journal Agronomy, 9:01-08.

Cardozo MTD, Galbiatti JA, Santana MJ, Caetano MCT, Carraschi S \& Nobile FO (2016) Pimentão (Capsicum annuum) fertilizado com composto orgânico e irrigado com diferentes lâminas de irrigação. Irriga, 21:673-684.

Carr MKV (2013) The water relations and irrigation requirements of passion fruit (Passiflora edulis Sims): A review. Experimental Agriculture, 49:585-596.
Cavichioli JC, Ruggiero C, Volpe CA, Paulo EM, Fagundes JL \& Kasai FS (2006) Florescimento e frutificação do maracujazeiro-amarelo submetido à iluminação artificial, irrigação e sombreamento. Revista Brasileira de Fruticultura, 28:92-96.

Demmig-Adams B \& Adams III (2006) Photoprotection in an ecological context: the remarkable complexity of thermal energy dissipation. New Phytologist, 172:11-21.

Efeoðlu B, Ekmekçi Y \& Çiçek N (2009) Physiological responses of three maize cultivars to drought stress and recovery. South African Journal of Botany, 75:34-42

Embrapa (2013) Sistema Brasileiro de Classificação de Solos. Rio de Janeiro, Embrapa Solos. 353p.

Fagundes MCP, Cruz MCM, Carvalho RP, Oliveira J \& Soares BC (2015) Polímero hidroabsorvente na redução de nutrientes lixiviados durante a produção de mudas de maracujazeiro amarelo. Revista Caatinga, 28:121- 129.

Felippe D, Navroski MC, Sampietro JA, Frigotto T, Albuquerque JA, Mota CS \& Pereira MO (2016) Efeito do hidrogel no crescimento de mudas de Eucalyptus benthamii submetidas a diferentes frequências de irrigação. Revista Floresta, 46:215-225.

Fischer IH, Arruda MC, Almeida AM, Garcia MJM, Jeronimo EM, Pinotti RN \& Bertani RMA (2007) Doenças e características físicas e químicas pós-colheita em maracujá amarelo de cultivo convencional e orgânico no centro oeste paulista. Revista Brasileira de Fruticultura, 29:254-259.

Freire JLO, Cavalcante LF, Rebequi AM, Dias TJ \& Souto AGL (2011) Necessidade hídrica do maracujazeiro amarelo cultivado sob estresse salino, biofertilização e cobertura do solo. Revista Caatinga, 24:82-91.

Freire JLO, Dias TJ, Cavalcante LF, Fernandes PD \& Lima Neto AJ (2014) Rendimento quântico e trocas gasosas em maracujazeiro amarelo sob salinidade hídrica, biofertilização e cobertura morta. Revista Ciências Agronômica, 45:82-91.

Gama VN, Cunha JT, Lima IM, Bacarin MA \& Silva DM (2013) Photosynthetic characteristics and quality of five passion fruit varieties under field conditions. Acta Physiology Plant, 35:941948 .

Godim SC, Cavalcante LF, Campos VB, Mesquita EF \& Gondim P C (2009) Produção e composição foliar do maracujazeiro amarelo sob lâminas de irrigação. Revista Caatinga, 22:100-107.

Gomes MTG, Luz AC, Santos MR, Batitucci MCP, Silva DM \& Falqueto AR (2012) Drought tolerance of passion fruit plants assessed by the OJIP chlorophyll a fluorescence transient. Scientia horticulturae, 142:49-56.

Kalaji HM, Jajoo A, Oukarroum A, Brestic M, Zivcak M, Samborska IA, Cetner MD, £ukasik I, Goltsev V \& Ladle RJ (2016) Chlorophyll a fluorescence as a tool to monitor physiological status of plants under abiotic stress conditions. Acta Physiology Plant, 38:4-11.

Kelling MB, Araujo MM, León EB, Aimi SC \& Turchetto F (2017) Regímenes de riego y dosis de polímero hidroretenedor sobre características morfológicas y fisiológicas de plantas de Cordia trichotoma. Bosque, 38:123-131.

Long SP \& Humphries S (1994) Photoinhibition of photosynthesis in nature. Annual Review of Plant Biology, 45:633-662.

Lopes MBS, Tavares TCO, Veloso DA, Silva NC \& Fidelis RR (2017) Cowpea bean production under water stress using hydrogels. Pesquisa Agropecuária Tropical, 47:87-92.

Mantovani EC, Delazari FT, Dias LE, Assis IR, Vieira GHS \& Landim FM (2013) Eficiência no uso da água de duas cultivares de batata-doce em resposta a diferentes lâminas de irrigação. Horticultura Brasileira, 31:602- 606. 
Martinazzo EG, Perboni AT, Oliveira PV, Bianchi VJ \& Bacarin MA (2013) Atividade fotossintética em plantas de ameixeira submetidas ao déficit hídrico e ao alagamento. Ciência Rural, 43:1-7.

Maxwell K \& Johnson GN (2000) Chlorophyll fluorescence - a practical guide. Journal of experimental botany, 51:659-668.

Medeiros SAS, Cavalcante LF, Bezerra MAF, Nascimento JAM, Bezerra FTC \& Prazeres ES (2016) Água salina e biofertilizante de esterco bovino na formação e qualidade de mudas de maracujazeiro amarelo. Irriga, 21:779-795

Meletti LMM (2011) Avanços da cultura do maracujá no Brasil. Revista Brasileira de Fruticultura, 33:83-91.

Melo AS, Suassuna JF, Fernandes PD, Brito MEB, Suassuna AF \& Aguiar Netto AO (2010) Crescimento vegetativo, resistência estomática, eficiência fotossintética e rendimento do fruto da melancieira em diferentes níveis de água. Acta Scientiarum Agronomy, 32:73-79.

Monteiro Neto, JLL, Araújo, WF, Chagas, EA, Siqueira, RHS, Oliveira, GA \& Abanto-Rodriguez, C (2017) Hydrogels in Brazilian agriculture. Revista Agro@mbiente On-line, 11:347360
Pinnola A \& Bassi R (2018) Molecular mechanisms involved in plant photoprotection. Biochemical Society Transactions, 46:467-482.

Santos HT, Carvalho DF, Souza CF \& Medici LO (2015) Cultivo de alface em solos com hidrogel utilizando irrigação automatizada. Engenharia Agrícola, 35:852-862.

Stone LF \& Silveira PM (1995) Determinação da evapotranspiração para fins de irrigação. Goiania, Embrapa/Cnpaf. 49p.

Vasconcelos D, Sousa VF, Viana TVA, Azevedo BM, Sousa GG \& Cavalcante Júnior JAH (2013) Interação entre níveis de irrigação e fertirrigação potássica na cultura do maracujazeiro. Irriga, 18:160-170

Wang Z, Kang S, Jensen CR \& Liu F (2012) Alternate partial rootzone irrigation reduces bundle-sheath cell leakage to $\mathrm{CO}_{2}$ and enhances photosynthetic capacity in maize leaves. Journal of experimental botany, 63:1145-1153.

Zlatev Z \& Lidon FC (2012) An overview on drought induced changes in plant growth, water relations and photosynthesis. Emirates Journal of Food and Agriculture. 24:57-72. 